\title{
Synthesis, Characterization and Biological Application of Rhodium, Platinum and Gold Metal Complexes Derived from Bidentate Schiff Base Ligand
}

\author{
Manik Rathod and Vijaykumar L. Chavan* \\ Department of Chemistry, Ramnarain Ruia Autonomous College, L. N. Road, Matunga (E), \\ Mumbai-400019, India.
}

Received: 22 Oct 2020 / Accepted: 20 Nov 2020/ Published online: 01 Jan 2021 *Corresponding Author Email: vijay.chavvan@gmail.com

\begin{abstract}
The derived bidentate schiff base ( $\mathrm{N}-(2-((\mathrm{E})-4$ hydroxy benzylidene) amino) phenyl)-1-( $\mathrm{p}$ tolyl) methenamine) by condensing 4-Hydroxy Benzaldehyde and o-Phenylenediamine have been synthesized. The above synthesized Schiff base forms stable coordinated metal complexes, using salts of Rhodium, Platinum and Gold. The synthesized Schiff base and metal complexes were characterized by U.V, FTIR, ${ }^{1} \mathrm{H}-\mathrm{NMR}$ and the percentage of elemental detections were determined by CHNS analyzer. The thermal stability of metal complexes was studied using TGA indicating the synthesized metal complexes up to $450-650{ }^{\circ} \mathrm{C}$. The characterization study confirms the formation of stable octahedral Rh (III) complex whereas Pt (II) and Au (III) complexes shows square planar structures. The crystal systems of the metal complexes were studied X-ray diffractometer. Further the comparative antimicrobial activities of the Schiff base and corresponding metal complexes have been studied.
\end{abstract}

Keywords

Antimicrobial activity, Metal complexes, Schiff bases, Spectral studies.

$* * * * *$

\section{INTRODUCTION:}

A large number of studies have been published on Schiff bases and their metal complexes. In general Schiff bases show very good coordinating ability with the transition metal ions. ${ }^{[1][2][3]}$ The variety of studies on transition metal complexes of Schiff bases show interesting properties such as chemical, antimicrobial, analytical as well as physiochemical effects. ${ }^{[4]-[8]}$ We tried to synthesize, characterized the Rh(III), Pt(II) and Au(III) complexes of Schiff base derived from 4-Hydroxy Benzaldehyde and oPhenylenediamine and also studied their biological activities and crystal lattice parameter of corresponding metal Schiff base complexes.

\section{MATERIALS AND METHODS:}

Chemicals

All the chemicals used were of Analytical reagent grade. 4-Hydroxy Benzaldehyde, oPhenylenediamine metal salts were obtained from S.D. fine-Chem. Ltd. Distilled solvents were used throughout the experiments. Purity of the synthesized Schiff base and metal complexes were checked by TLC using Merck silica gel plates. The melting points of all the Schiff base compounds were obtained on a VMP-D /DS melting point apparatus. The percentages of $\mathrm{C}, \mathrm{H} \& \mathrm{~N}$ in Schiff base metal complexes were determined using a Thermo finnigan FLASH EA 1112 series CHN analyzer. The IR spectra were recorded in $\mathrm{KBr}$ pellets on Shimadzu IR Prestige 
21. UV Visible spectra were recorded with Shimadzu UV1800A spectrophotometer. ECZR Series $600 \mathrm{MHz}$ NMR spectrometer were used for $1 \mathrm{H}$ NMR. XRD analysis were done using LabX XRD-6100 whereas thermal analysis were done using Perkin Elmer 4000. The antimicrobial activity of the Schiff base and their complexes are determined by the zone inhibition method against bacterial strains of Staphylacoccus aureus, Staphylacoccus pyogenes, Escherichia coli and Klebsiella Pneumonia.

Synthesis of Ligand (HL): N-(2-((E)-4 hydroxy benzylidene) amino) phenyl)-1- (p tolyl) methenamine.

Procedure: The Schiff base was prepared by condensing (1:2) quantities of o-Phenylenediamine (1.08g) and 4-Hydroxy Benzaldehyde (2.44g) respectively. Using two-neck round bottom flask, 25 $\mathrm{mL}$ hot alcoholic solution of 4-Hydroxy Benzaldehyde was slowly added to $25 \mathrm{~mL}$ hot alcoholic solution of o-Phenylenediamine. The reaction mixture was then refluxed for five hours on water bath then hot reaction mixture was poured in ice-cold water. The precipitate obtained was filtered, washed with cold water, recrystallized from ethanol and air dried. Its physical and analytical data given in (TABLE 1).

Synthesis of Metal Complexes:

Synthesis of $\left[\mathrm{Rh}(\mathrm{HL}) \mathrm{Cl}_{3} \mathrm{H}_{2} \mathrm{O}\right] .2 \mathrm{H}_{2} \mathrm{O}$ :

Procedure: The metal complex was synthesized by reflux-precipitation method in a two necked round bottom flask. The hot alcoholic solution of Schiff base (HL) $(0.001 \mathrm{~mol})$ was mixed with alcoholic solution of with constant stirring. The Rh (III) complex Rh (III) was precipitated at $\mathrm{pH}=8.50$ by refluxing alcoholic solution of Schiff base $(0.001 \mathrm{~mol})$ with $\mathrm{RhCl}_{3 .} 3 \mathrm{H}_{2} \mathrm{O}$ $(0.001 \mathrm{~mol})$ for about $6-8$ hours. The buff-colored metal complexes separated were filtered, washed with hot water and then with $5 \%$ hot ethanol, air dried and melting point recorded.

Synthesis of $\left[\mathrm{Pt}\left(\mathrm{HL}_{)} \mathrm{Cl}_{2}\right]\right.$. $\mathrm{H}_{2} \mathrm{O}$ :
Procedure: The Pt (II) metal complex was synthesized by reflux-precipitation method in a two necked round bottom flask. The hot alcoholic solution of Schiff base (HL) $(0.001 \mathrm{~mol})$ was mixed with alcoholic solution of $\mathrm{K}_{2} \mathrm{PtCl}_{4}$ (0.001 mol) with constant stirring. The $\mathrm{pH}$ of reaction mixture was adjusted to 3.26 . The red coloured precipitate $\mathrm{Pt}$ (II) metal complex separated was filtered, washed with hot water and then with $5 \%$ hot ethanol air dried and melting point was recorded.

Synthesis of [Au ( $\left.\mathrm{HL}) \mathrm{Cl}_{2}\right] \mathrm{Cl} \cdot \mathrm{H}_{2} \mathrm{O}$ :

Procedure: The $\mathrm{Au}$ (III) metal complex was synthesized by reflux-precipitation method in a two necked round bottom flask. The hot alcoholic solution of Schiff base ( $\mathrm{HL}$ ) (0.001 mol) was mixed with alcoholic solution of $\mathrm{NaAuCl}_{4} .2 \mathrm{H}_{2} \mathrm{O}(0.001$ mol) with constant stirring. The $\mathrm{pH}$ of reaction mixture was adjusted to 3.26. The reddish-brown colored $\mathrm{Au}$ (III) metal complex precipitated was separated, filtered, washed with hot water and then with $5 \%$ hot ethanol, air dried and melting point was recorded.

The physical and analytical data of metal complexes are given in (TABLE 1).

\section{RESULTS AND DISCUSSION:}

The Schiff base is synthesized by using equimolar quantities of 4-Hydroxyl Benzaldehyde and oPhenylenediamine. The metal complexes of Rh (III), Pt (II) and Au (III) were synthesized using 1:1 stoichiometric proportions. The metal complexes derived varied in their color. All the complexes are air stable, non-hygroscopic, colored solids. The metal complexes are insoluble in water but soluble in DMSO and DMF. All the complexes show very low molar conductance values which indicate that the complexes are non-electrolytic in nature. The physical and analytical data of Schiff base and metal complexes are shown in (TABLE 1).

TABLE 1: PHYSICAL AND ANALYTICAL DATA OF SCHIFF BASE AND ITS METAL COMPLEXES

\begin{tabular}{|c|c|c|c|c|c|c|c|c|c|}
\hline \multirow[t]{2}{*}{$\begin{array}{l}\text { Ligand/ } \\
\text { Complexes }\end{array}$} & \multirow[t]{2}{*}{ Colour } & \multirow[t]{2}{*}{ M.P. ${ }^{\circ} \mathrm{C}$} & \multirow{2}{*}{$\begin{array}{l}\text { Mol. } \\
\text { Wt. } \\
\text { g }\end{array}$} & \multicolumn{5}{|c|}{$\begin{array}{l}\text { Elemental analysis \% } \\
\text { Calculated } \\
\text { (Found) }\end{array}$} & \multirow[t]{2}{*}{$\begin{array}{l}\text { Molar } \\
\text { Cond. } \\
\left(\mathrm{Scm}^{2} \mathrm{~mol}^{-1}\right)\end{array}$} \\
\hline & & & & C & $\mathrm{H}$ & $\mathbf{N}$ & $\mathrm{Cl}$ & Metal & \\
\hline$H L$ & Pale Yellow & 135 & 316.36 & $\begin{array}{l}75.94 \\
(74.57)\end{array}$ & $\begin{array}{l}5.06 \\
(5.24)\end{array}$ & $\begin{array}{l}8.86 \\
(8.82)\end{array}$ & - & - & - \\
\hline$\left[\mathrm{Rh}(\mathrm{HL}) \mathrm{Cl}_{3} \mathrm{H}_{2} \mathrm{O}\right] \cdot 2 \mathrm{H}_{2} \mathrm{O}$ & Dark Brown & 185 & 577.68 & $\begin{array}{l}41.59 \\
(42.10)\end{array}$ & $\begin{array}{l}3.81 \\
(3.20)\end{array}$ & $\begin{array}{l}4.85 \\
(4.92)\end{array}$ & $\begin{array}{l}18.19 \\
(18.48)\end{array}$ & $\begin{array}{l}17.85 \\
(17.32)\end{array}$ & 0.030 \\
\hline$\left[\mathrm{Pt}(\mathrm{HL}) \mathrm{Cl}_{2}\right] \mathrm{H}_{2} \mathrm{O}$ & Brown & 210 & 599.03 & $\begin{array}{l}40.06 \\
(45.38)\end{array}$ & $\begin{array}{l}3.00 \\
(3.01)\end{array}$ & $\begin{array}{l}4.60 \\
(4.81)\end{array}$ & $\begin{array}{l}11.62 \\
(11.40)\end{array}$ & $\begin{array}{l}32.55 \\
(33.72)\end{array}$ & 0.048 \\
\hline$\left[\mathrm{Au}(\mathrm{HL}) \mathrm{Cl}_{2}\right] \mathrm{Cl} . \mathrm{H}_{2} \mathrm{O}$ & Brown & 162 & 637.26 & $\begin{array}{l}37.79 \\
(38.01)\end{array}$ & $\begin{array}{l}2.83 \\
(2.38) \\
\end{array}$ & $\begin{array}{l}4.40 \\
(4.09) \\
\end{array}$ & $\begin{array}{l}16.62 \\
(16.10)\end{array}$ & $\begin{array}{l}30.25 \\
(30.41)\end{array}$ & 0.094 \\
\hline
\end{tabular}


The FTIR spectral data of the Schiff base and the Metal Complexes:

The I.R. spectral data of the Schiff base and the Metal Complexes are recorded in TABLE 2A. Schiff base showed a strong absorption band at $1623 \mathrm{~cm}^{-1}$ characteristic of $\mathrm{U}(\mathrm{C}=\mathrm{N})$. The azomethine $\mathrm{U}(\mathrm{C}=\mathrm{N})$ band at $1623 \mathrm{~cm}^{-1}$ in Schiff base is shifted to lower frequency in $\mathrm{Rh}$ (III), Pt(II) and $\mathrm{Au}$ (III) complexes by $12 \mathrm{~cm}^{-1}, 9$ $\mathrm{cm}^{-1}$ and $10 \mathrm{~cm}^{-1}$ respectively which indicates the coordination of azomethine nitrogen in complexation. ${ }^{[12]}$ The values around $3600-3550 \mathrm{~cm}^{-1}$ indicates free $-\mathrm{OH}$ stretching frequency in case of ligand and metal complexes. Thus it suggests that the phenolic oxygen of Schiff base is not coordinated with the metal. The new frequency band observed from $550-580 \mathrm{~cm}^{-1}$ indicates formation of $\mathrm{M}-\mathrm{N}$ bond whereas frequency band observed from $320-330 \mathrm{~cm}^{-}$ ${ }^{1}$ indicates formation of $\mathrm{M}-\mathrm{X}$ bond.

Electronic Spectral data of the Schiff base and the Metal Complexes:

Electronic spectrum of ligand showed three high intensity bands at $20833 \mathrm{~cm}^{-1}, 22540 \mathrm{~cm}^{-1}$ and 36487 $\mathrm{cm}^{-1}$ indicates $\mathrm{n} \rightarrow \mathrm{n}^{*}$ and $\sigma \rightarrow \sigma^{*}$ transitions.
The electronic spectra of $\mathrm{Pt}(\mathrm{II})$ complex showed bands at $21250 \mathrm{~cm}^{-1}, 25970 \mathrm{~cm}^{-1}$ and $30950 \mathrm{~cm}^{-1}$ which may be assigned to ${ }^{1} \mathrm{~A}_{1 \mathrm{~g}} \rightarrow{ }^{1} \mathrm{~B}_{1 \mathrm{~g}},{ }^{1} \mathrm{~A}_{1 \mathrm{~g}} \rightarrow{ }^{1} \mathrm{E}_{1 \mathrm{~g}}$ and ${ }^{1} A_{1 g} \rightarrow{ }^{1} A_{2 g}$ respectively. The band at $36870 \mathrm{~cm}^{-1}$ is considered as charge transfer transition. Hence, a square planar geometry may be assigned for Pt (II) complex. [15]

Similarly the electronic spectra of $A u(I I I)$ complex showed bands at $21260 \mathrm{~cm}^{-1}, 25290 \mathrm{~cm}^{-1}$ and 30250 $\mathrm{cm}^{-1}$ which may be assigned to ${ }^{1} \mathrm{~A}_{1 \mathrm{~g}} \rightarrow{ }^{1} \mathrm{~B}_{1 \mathrm{~g}},{ }^{1} \mathrm{~A}_{1 \mathrm{~g}} \rightarrow{ }^{1} \mathrm{E}_{1 \mathrm{~g}}$ and ${ }^{1} A_{1 g} \rightarrow{ }^{1} A_{2 g}$ respectively. The band at $33200 \mathrm{~cm}^{-1}$ is considered as charge transfer transition. Hence, a square planar geometry may be assigned for Au (III) complex ${ }^{[16]}$

The electronic spectrum of Rh(III) complex showed bands at $22230 \mathrm{~cm}^{-1}$ and $25650 \mathrm{~cm}^{-1}$ which have been assigned to ${ }^{1} \mathrm{~A}_{1 \mathrm{~g}} \rightarrow{ }^{1} \mathrm{~T}_{1 \mathrm{~g}}$ and ${ }^{1} \mathrm{~A}_{1 \mathrm{~g}} \rightarrow{ }^{1} \mathrm{~T}_{2 \mathrm{~g}}$ transitions respectively whereas the band appearing at 38750 $\mathrm{cm}^{-1}$ is a charge transfer transition. ${ }^{[17]}$ The $\mathrm{Rh}$ (III) complex may be assigned octahedral geometry ${ }^{[18]}$. The Electronic spectral data have shown in TABLE 2B.

TABLE 2A: FTIR DATA

\begin{tabular}{|c|c|c|c|c|}
\hline \multirow{2}{*}{ Ligand/Complexes } & \multicolumn{4}{|c|}{ I.R Spectral data $\mathrm{cm}^{-1}$} \\
\hline & $U(\mathrm{O}-\mathrm{H})$ & $U(C=N)$ & $U(M-N)$ & $U(M-X)$ \\
\hline$(\mathrm{HL})$ & $\begin{array}{l}3540 \\
(b r)\end{array}$ & $\begin{array}{l}1623 \\
\text { (s) }\end{array}$ & ----- & --- \\
\hline$\left[\mathrm{Rh}(\mathrm{HL}) \mathrm{Cl}_{3} \mathrm{H}_{2} \mathrm{O}\right] \cdot 2 \mathrm{H}_{2} \mathrm{O}$ & $\begin{array}{l}3550 \\
(b r)\end{array}$ & $1611(s)$ & $\begin{array}{l}570 \\
(\mathrm{~m})\end{array}$ & $\begin{array}{l}330 \\
(\mathrm{~m})\end{array}$ \\
\hline$\left[\mathrm{Pt}(\mathrm{HL}) \mathrm{Cl}_{2}\right] \mathrm{H}_{2} \mathrm{O}$ & $\begin{array}{l}3542 \\
\text { (br) }\end{array}$ & $1614(\mathrm{~s})$ & $\begin{array}{l}565 \\
(\mathrm{~m})\end{array}$ & $\begin{array}{l}325 \\
(\mathrm{~m})\end{array}$ \\
\hline$\left[\mathrm{Au}(\mathrm{HL}) \mathrm{Cl}_{2}\right] \mathrm{Cl} . \mathrm{H}_{2} \mathrm{O}$ & $\begin{array}{l}3545 \\
\text { (br) }\end{array}$ & $1613(\mathrm{~s})$ & $\begin{array}{l}568 \\
(\mathrm{~m})\end{array}$ & $\begin{array}{l}335 \\
(\mathrm{~m})\end{array}$ \\
\hline
\end{tabular}

$* s=\operatorname{sharp} b r=$ broad $m=$ medium

TABLE 2B: ELECTRONIC SPECTRAL DATA

\begin{tabular}{ll}
\hline Ligand/Complexes & Electronic spectral data $\mathbf{~ c m}^{-1}$ \\
\hline$(\mathrm{HL})$ & 20833,22540 and 36487 \\
{$\left[\mathrm{Rh}(\mathrm{HL}) \mathrm{Cl}_{3} \mathrm{H}_{2} \mathrm{O}\right] \cdot 2 \mathrm{H}_{2} \mathrm{O}$} & 22230,25650 and 38750 \\
{$\left[\mathrm{Pt}(\mathrm{HL}) \mathrm{Cl}_{2}\right] \mathrm{H}_{2} \mathrm{O}$} & $21250,25970,30950$ and 36870 \\
{$\left[\mathrm{Au}(\mathrm{HL}) \mathrm{Cl}_{2}\right] \mathrm{Cl} \cdot \mathrm{H}_{2} \mathrm{O}$} & $21260,25290,30250$ and 33200 \\
\hline
\end{tabular}

${ }^{1} \mathrm{H}$ NMR:

The ${ }^{1} \mathrm{H}$ NMR spectra of Schiff base and its metal complexes were recorded in DMSO. The aromatic protons in Schiff base were appeared in the range 6.85-7.66 ppm and metal complexes were appeared in the range $6.70-8.25 \mathrm{ppm}$. The azomethine proton in Schiff base appeared $(\delta=8.64 \mathrm{ppm})$ have showed downfield shifting in metal complexes $(\delta=8.72-8.88$ $\mathrm{ppm}$ ) this indicates the co-ordination of azomethine nitrogen atom in metal complexation. The appearance of peaks ( $\delta=9.65-9.68 \mathrm{ppm})$ indicates the presence of hydroxyl protons and also suggests no 
deprotonation of hydroxyl proton. The NMR spectral data have shown in TABLE 3 A.

TABLE 3A: ${ }^{1} \mathrm{H}$ NMR SPECTRAL DATA

\begin{tabular}{|c|c|c|c|}
\hline \multirow{2}{*}{ Ligand/Complexes } & \multicolumn{3}{|c|}{${ }^{1} \mathrm{H}$ NMR ( $\left.\delta \mathrm{ppm}\right)$} \\
\hline & $\mathrm{Ar}-\mathrm{OH}$ & $\mathrm{CH}=\mathrm{N}$ & Ar-H \\
\hline$(\mathrm{HL})$ & 9.68 & 8.64 & $6.85-7.66$ \\
\hline$\left[\mathrm{Rh}(\mathrm{HL}) \mathrm{Cl}_{3} \mathrm{H}_{2} \mathrm{O}\right] \cdot 2 \mathrm{H}_{2} \mathrm{O}$ & 9.65 & 8.72 & $6.70-8.25$ \\
\hline$\left[\mathrm{Pt}(\mathrm{HL}) \mathrm{Cl}_{2}\right] \mathrm{H}_{2} \mathrm{O}$ & 9.68 & 8.83 & $6.70-8.25$ \\
\hline$\left[\mathrm{Au}(\mathrm{HL}) \mathrm{Cl}_{2}\right] \mathrm{Cl} \cdot \mathrm{H}_{2} \mathrm{O}$ & 9.67 & 8.88 & $6.70-8.25$ \\
\hline
\end{tabular}

\section{Thermal analysis:}

The thermal analysis of the metal complexes was carried out to get information about the stability of the metal complexes and amount of organic content present in complexes. Thermal analysis was carried out in the range $30-1000^{\circ} \mathrm{C}$ at $10^{\circ} \mathrm{C} / \mathrm{min}$. The $\mathrm{Rh}$ (III), Pt(II) and $\mathrm{Au}(\mathrm{III})$ complexes have shown the initial weight loss of $6.27 \%, 3.00 \%$, and $8.39 \%$ respectively in the temperature range $30-100^{\circ} \mathrm{C}$ which indicates the presence of two and one molecules of water in $\mathrm{Rh}$ (III) and $\mathrm{Pt}$ (II) complexes respectively. In Aurum complex, one molecule of lattice water in all the complexes along with loss of chloride ion from. ${ }^{[19]}$

The Rh (III) complex have shown weight loss by 3.11 $\%$ in the temperature range $110^{\circ} \mathrm{C}-160^{\circ} \mathrm{C}$ indicating the presence of one molecule of coordinated water in Rh (III) complex. Rh (III), Pt(II) and $\mathrm{Au}$ (III) complexes have shown weight loss by $73.05 \%, 64.44$ $\%$ and $55.76 \%$ indicating the loss of organic content resulting in the formation of corresponding oxides with further increase in the temperature. The thermal data and graphs have shown in TABLE 3B and in Figure No 1, 2 and 3.

TABLE 3B: THERMAL DATA

\begin{tabular}{lllllll}
\hline \multirow{2}{*}{ Ligand/Complexes } & \multicolumn{2}{l}{ Calculated \% } & \multicolumn{3}{l}{ Found \% } \\
\cline { 2 - 7 } & $\begin{array}{l}\text { Lattice } \\
\text { Content }\end{array}$ & $\begin{array}{l}\text { Co-ordinated } \\
\text { Water }\end{array}$ & $\begin{array}{l}\text { Organic } \\
\text { Content }\end{array}$ & $\begin{array}{l}\text { Lattice } \\
\text { Content }\end{array}$ & $\begin{array}{l}\text { Co-ordinated } \\
\text { Water }\end{array}$ & $\begin{array}{l}\text { Organic } \\
\text { Content }\end{array}$ \\
\hline$\left[\mathrm{Rh}(\mathrm{HL}) \mathrm{Cl}_{3} \mathrm{H}_{2} \mathrm{O}\right] .2 \mathrm{H}_{2} \mathrm{O}$ & 6.23 & 3.11 & 73.05 & 6.16 & 3.84 & 72.99 \\
{$\left[\mathrm{Pt}(\mathrm{HL}) \mathrm{Cl}_{2}\right] \mathrm{H}_{2} \mathrm{O}$} & 3.00 & - & 64.44 & 3.15 & - & 64.76 \\
{$\left[\mathrm{Au}(\mathrm{HL}) \mathrm{Cl}_{2}\right] \mathrm{Cl} . \mathrm{H}_{2} \mathrm{O}$} & 8.39 & - & 55.76 & 8.89 & - & 58.58 \\
\hline
\end{tabular}

Graphical images of thermal analysis of metal complexes

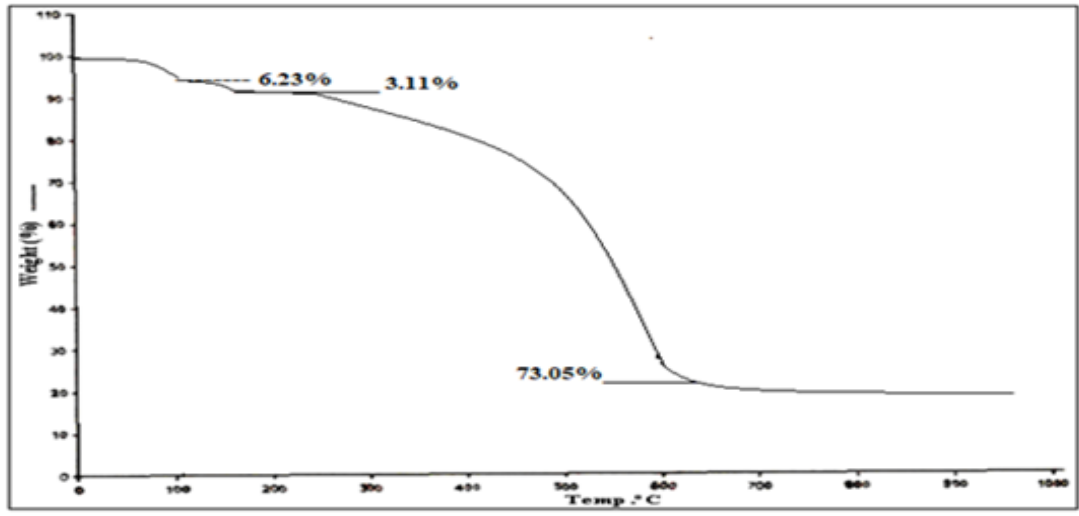

Figure.No 1 : TGA of $\left[\mathrm{Rh}(\mathrm{HL}) \mathrm{Cl}_{3} \mathrm{H}_{2} \mathrm{O}\right] .2 \mathrm{H}_{2} \mathrm{O}$ 


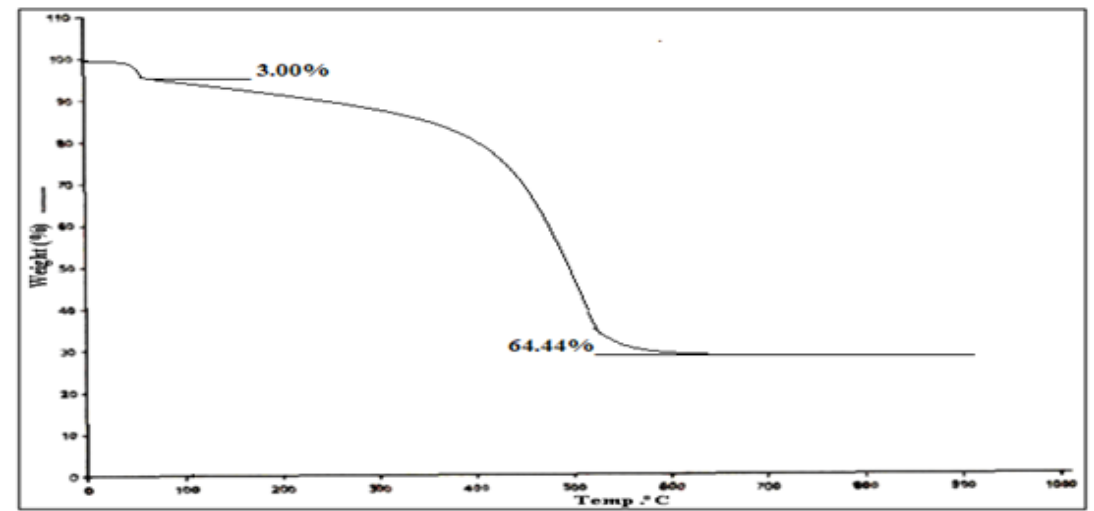

Figure. No 2 : TGA of $\left[\mathrm{Pt}(\mathrm{HL}) \mathrm{Cl}_{2}\right] \mathrm{H}_{2} \mathrm{O}$

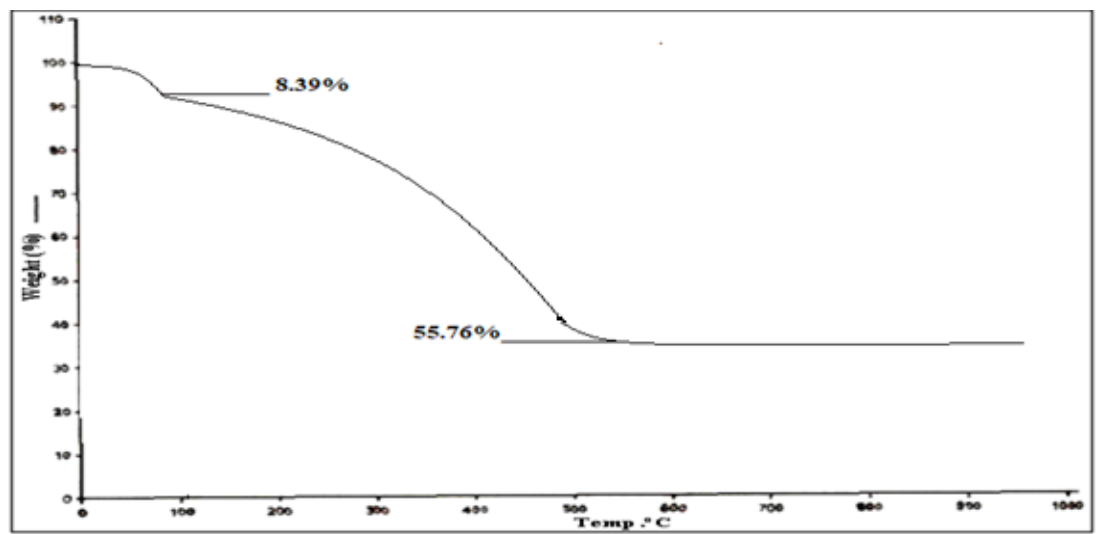

Figure. No 3 : TGA of $\left[\mathrm{Au}(\mathrm{HL}) \mathrm{Cl}_{2}\right] \mathrm{Cl} .2 \mathrm{H}_{2} \mathrm{O}$

Structure of Rh (III), Pt (II) and Au (III) complexes: The Schiff base of 4-Hydroxyl Benzaldehyde and oPhenylenediamine and its $\mathrm{Rh}$ (III), $\mathrm{Pt}(\mathrm{II})$ and $\mathrm{Au}$ (III) complexes were characterized by elemental analysis, spectral studies $\left({ }^{1} \mathrm{H}\right.$ NMR, IR, UV-Vis.), molar conductance and thermal analysis. Based on above data Pt (II) and Au (III) complex show square planar structure whereas Rh (III) complex show octahedral structure. The synthesis and structures of the Schiff Base have shown in Figure No 4. whereas the proposed structures of the metal complexes have shown in Figure No 5, 6 and 7 for Rh (III), Pt (II) and $\mathrm{Au}$ (III) respectively.

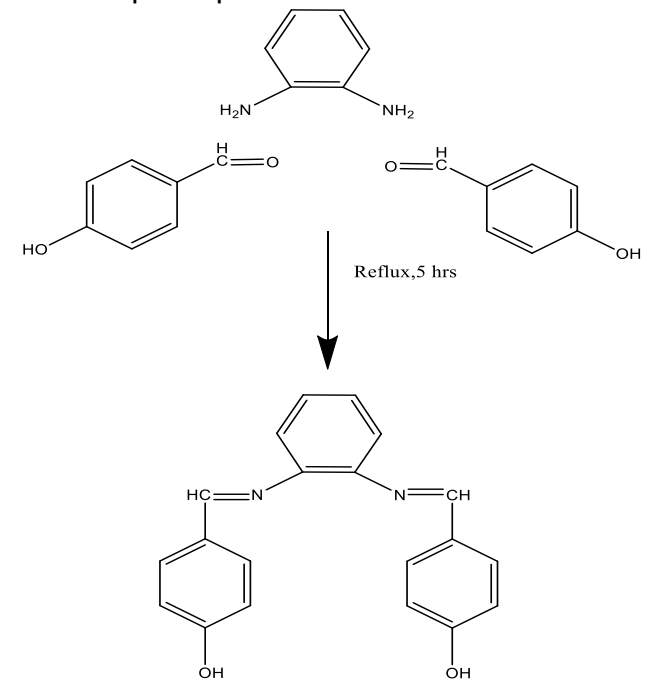

Figure No.4. Structure and synthesis of Schiff base (HL). 


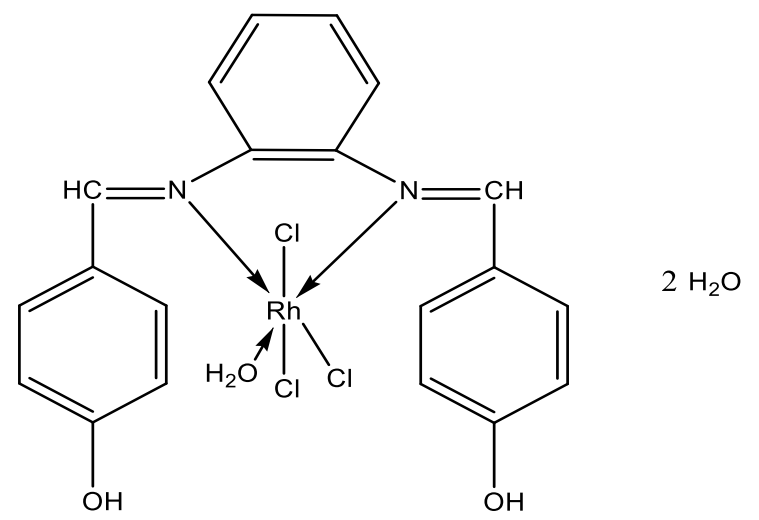

Figure No.5. Structure of Rhodium (III) complex.<smiles>Oc1ccc(/C=N\N2N=Cc3ccccc3[P+](Cl)(Cl)N2)cc1</smiles>

Figure No.6. Structure of Pt (II)complex<smiles>CCCN1c2ccccc2CN(Cc2ccc(O)cc2)c2ccccc21</smiles>

Figure No.7. Structure of Au (III) complex.

X-Ray Studies of Rh (III), Pt (II) and Au (III) complexes:

The crystal structure of synthesized Rh(III), Pt(II) and $\mathrm{Au}$ (III)complexes was analyzed and studied using $\mathrm{X}$ ray diffractograms by scanning in the range $2 \theta=5^{\circ}$ $80^{\circ}$ and an independent indexing for the $\mathrm{X}$-ray powder diffraction data was done and compared to the documented X-Ray diffractograms. The original $\mathrm{X}$-ray diffractograms are reproduced in Figure No. 8, 9 and 10 for Rh (III), Pt (II) and Au (III) complexes, respectively. 


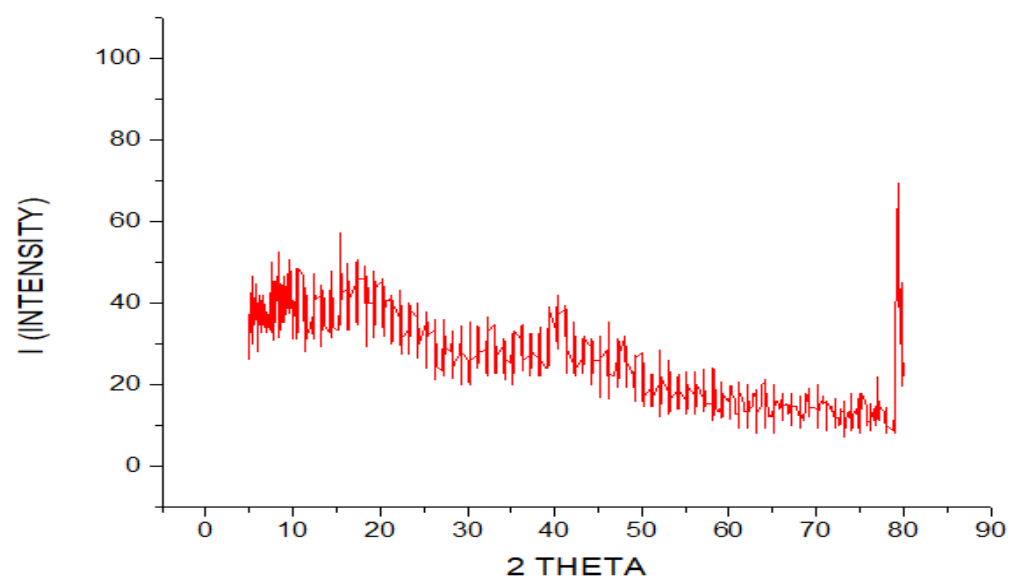

Figure. No $8:\left[\mathrm{Rh}(\mathrm{HL}) \mathrm{Cl}_{3} \mathrm{H}_{2} \mathrm{O}\right] .2 \mathrm{H}_{2} \mathrm{O}$

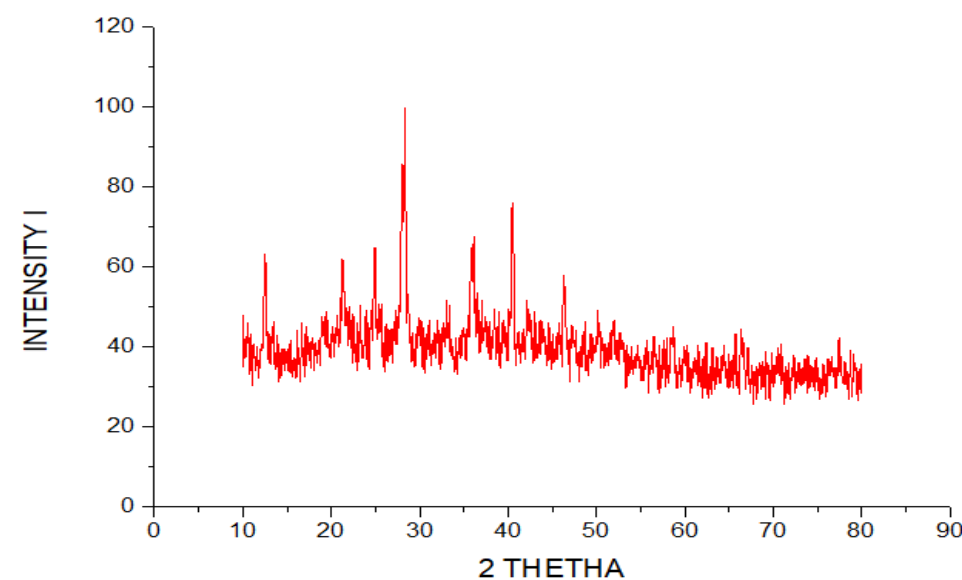

Figure.No.9 : $\left[\mathrm{Pt}(\mathrm{HL}) \mathrm{Cl}_{2}\right] \mathrm{H}_{2} \mathrm{O}$

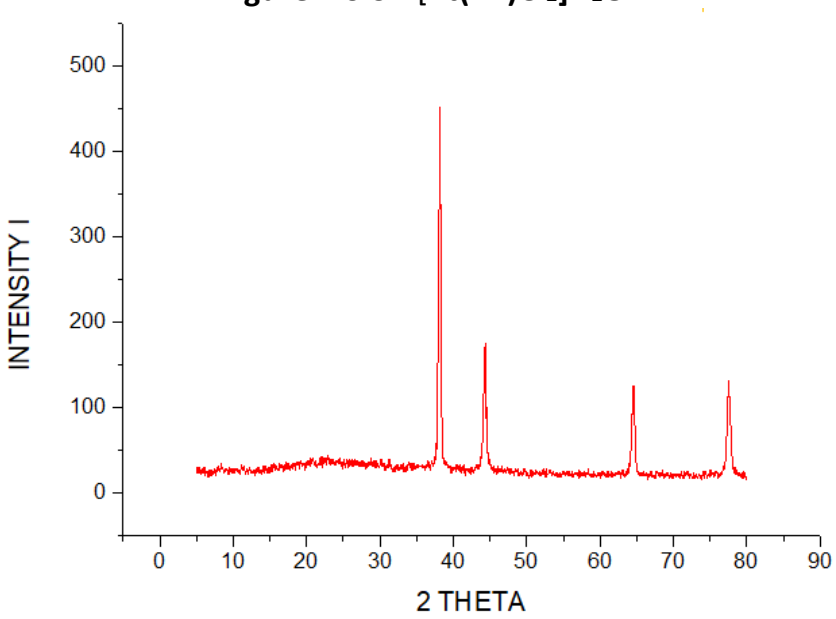

Figure.No.10:[Au(HL)Cl 2$] \mathrm{Cl}_{2} 2 \mathrm{H}_{2} \mathrm{O}$

The X-ray diffractogram of Rh (III) complex are good, complex were successfully indexed to monoclinic indicating the high crystalline nature. The Rh (III) crystal system having lattice parameters $a=15.2355$ 
$\AA$, $b=15.5224 \AA$ and $c=11.4099 \AA .{ }^{[20]}$ The X-ray data of the $R h$ (III) complex of (HL) having $M: L$ stoichiometry as 1:1 and can be assigned space group $\mathrm{P}_{2} / \mathrm{m}$ for with conditions on hkl values for. The calculated density of Rh (III) complexes of $(\mathrm{HL})$ is $1.806 \mathrm{~g} / \mathrm{cm}^{3}$.

The X-ray diffractogram of Pt (II) complex are good, indicating the high crystalline nature. The Pt (II) complex was successfully indexed to monoclinic crystal system having lattice parameters.

$a=14.0540 \AA, b=23.6330 \AA$ and $c=16.5250 \AA{ }^{[21]}$. The X-ray data of the Pt (II) complex of $(\mathrm{HL})$ having $\mathrm{M}: \mathrm{L}$ stoichiometry as $1: 1$ can be assigned space group
$\mathrm{P} 121 / \mathrm{n} 1$ for with conditions on $\mathrm{hkl}$ values for $\left[\mathrm{Pt}(\mathrm{HL}) \mathrm{Cl}_{2}\right] \mathrm{H}_{2} \mathrm{O}$. The calculated density of $\mathrm{Pt}$ (II) complex of $(\mathrm{HL})$ is $2.570 \mathrm{~g} / \mathrm{cm}^{3}$.

The X-ray diffractogram of Au (III) complex are good indicating the high crystalline nature The Au (III) complex was successfully indexed to cubic crystal system having lattice parameters.

$a=b=c=3.8560 \AA^{[19]}$. The X-ray data of the Au (III) complex of $(\mathrm{HL})$ having $M: L$ stoichiometry as $1: 1$ and can be assigned space group $\mathrm{Pm}-3 \mathrm{~m}$ for with conditions on hkl values for $\left[\mathrm{Au}(\mathrm{HL}) \mathrm{Cl}_{2}\right] \mathrm{Cl} . \mathrm{H}_{2} \mathrm{O}$. The calculated density of $\mathrm{Au}$ (III) complexes of $(\mathrm{HL})$ is $6.445 \mathrm{~g} / \mathrm{cm}^{3}$.

TABLE 4: CRYSTAL LATTICE PARAMETERS

\begin{tabular}{|c|c|c|c|c|c|c|}
\hline \multirow{2}{*}{ Complex } & \multirow{2}{*}{ Crystal system } & \multirow{2}{*}{ Space group } & \multicolumn{3}{|c|}{ Lattice parameters $\left(\mathrm{A}^{0}\right)$} & \multirow{2}{*}{$\begin{array}{l}\text { Density } \\
\mathrm{g} / \mathrm{cm}^{3}\end{array}$} \\
\hline & & & a & $\mathbf{b}$ & C & \\
\hline$\left[\mathrm{Rh}(\mathrm{HL}) \mathrm{Cl}_{3} \mathrm{H}_{2} \mathrm{O}\right] \cdot 2 \mathrm{H}_{2} \mathrm{O}$ & $\begin{array}{l}\text { Monoclinic } \\
\left(\alpha=\gamma=90^{\circ} \beta=98.05^{\circ}\right)\end{array}$ & $\mathrm{P}_{2} / \mathrm{m}$ & 15.235 & 15.5224 & 11.4099 & 1.806 \\
\hline$\left[\mathrm{Pt}(\mathrm{HL}) \mathrm{Cl}_{2}\right] \mathrm{H}_{2} \mathrm{O}$ & $\begin{array}{l}\text { Monoclinic } \\
(\alpha=\gamma=90 \stackrel{\circ}{ } \\
\beta=102.55 \stackrel{\circ}{ })\end{array}$ & P 1 21/n 1 & 14.054 & 14.054 & 16.525 & 2.570 \\
\hline$\left[\mathrm{Au}(\mathrm{HL}) \mathrm{Cl}_{2}\right] \mathrm{Cl} .2 \mathrm{H}_{2} \mathrm{O}$ & $\begin{array}{l}\text { Cubic } \\
(\alpha=\beta=\gamma=90 \stackrel{\circ}{ })\end{array}$ & $P m-3 m$ & 3.8560 & 3.8560 & 3.8560 & 6.445 \\
\hline
\end{tabular}

Antimicrobial Studies of Schiff bases and their Rh (III), Pt (II) and Au (III) metal complexes.

The majority of metal complexes possessing antimicrobial activity are chelates. The relationship of metal complexes to biological response has been investigated by the Kirby-Bauer test. The Kirby-Bauer test is a standard test used for antimicrobial susceptibility also called as the disc diffusion test. If the organism is killed or inhibited by the concentration of the antibiotic, there will be no growth in the immediate area around the disc. This area is called as the zone of inhibition. ${ }^{[25][29]}$

The biological screening effects of the investigated compounds were tested against the bacteria: Staphylacoccus aureus, Staphylacoccus pyogenes, Escherichia coli and Klebsiella Pneumonia, this was carried out by the disk diffusion technique, using agar nutrient as the medium. The stock solution (5mmol) of new compounds was prepared by dissolving the compounds in DMSO. In a typical procedure, a well was made on the agar medium inoculated with bacterial strains. The well was filled with the test solution using a micropipette and the plate was incubated for $24 \mathrm{~h}$ at $37^{\circ} \mathrm{C}$. During this period, the test solution diffused and the growth of the inoculated microorganisms was affected. The results were recorded by measuring the growth inhibition surrounding the disk.

The results (TABLE 5) reveal that the ligand is less active towards the bacterial strain. All metal complexes were found to have moderate activity and quite better activity over the ligand. In general it is concluded that metal complexes are more active than that of the corresponding ligand.

TABLE 5: ANTIBACTERIAL STUDIES OF SCHIFF BASES AND THEIR METAL COMPLEXES

\begin{tabular}{|c|c|c|c|c|c|}
\hline \multirow[t]{2}{*}{ Sr. No. } & \multirow[t]{2}{*}{ Compound } & \multicolumn{2}{|c|}{$\begin{array}{l}\text { Zone of inhibition for } \\
\text { Gram positive strain }(\mathrm{mm})\end{array}$} & \multicolumn{2}{|c|}{$\begin{array}{l}\text { Zone of inhibition for } \\
\text { Gram negative strain }(\mathrm{mm})\end{array}$} \\
\hline & & S. aureus & S. pyo & $K . P$ & E.coli \\
\hline 1 & $\mathrm{HL}$ & 02 & 04 & 00 & 00 \\
\hline 2 & {$\left[\mathrm{Rh}(\mathrm{HL}) \mathrm{Cl}_{3} \mathrm{H}_{2} \mathrm{O}\right] .2 \mathrm{H}_{2} \mathrm{O}$} & 07 & 08 & 03 & 03 \\
\hline 3 & {$\left[\mathrm{Pt}(\mathrm{HL}) \mathrm{Cl}_{2}\right] \mathrm{H}_{2} \mathrm{O}$} & 12 & 08 & - & 04 \\
\hline 4 & {$\left[\mathrm{Au}(\mathrm{HL}) \mathrm{Cl}_{2}\right] \mathrm{Cl} .2 \mathrm{H}_{2} \mathrm{O}$} & 09 & 12 & 02 & - \\
\hline
\end{tabular}




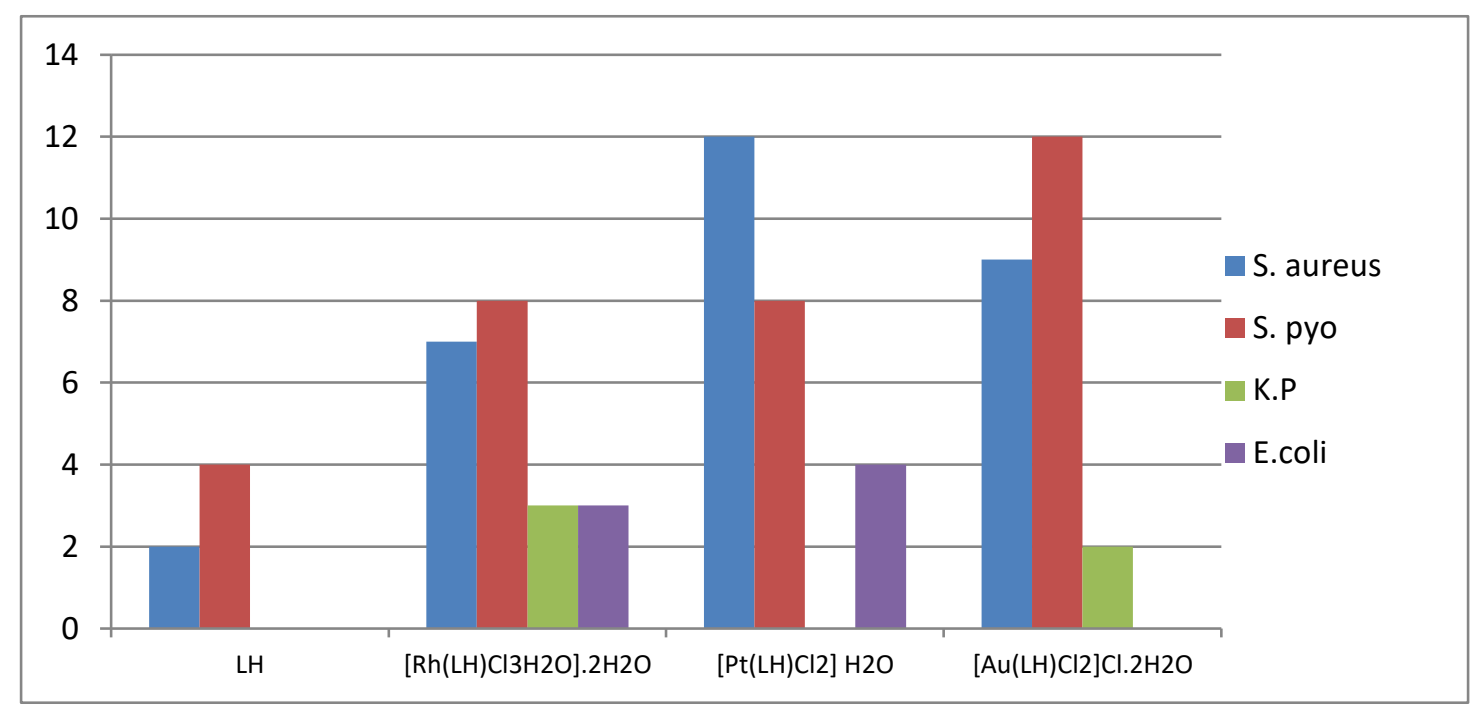

S. aureus:- Staphylacoccus aureus

S. pyo:- Staphylacoccus pyogenes

E.coli:- Escherichia coli K.P-:Klebsiella Pneumonia

\section{ACKNOWLEDGEMENT:}

We would like to thank IIT SAIF and PSRIC for analysis. We thank to the Principal and Head of Department of chemistry, Ramnarain Ruia college of Autonomous, for their co-operation and support.

\section{CONCLUSION:}

The Schiff base of 4-Hydroxyl Benzaldehyde and ophenyl diamine and its Rh (III) Pt (II) and Au (III) complexes were synthesized and characterized by elemental analysis, spectral studies ( ${ }^{1} \mathrm{HNMR}, \mathrm{IR}$, UVVis.), molar conductance and thermal analysis. On the basis of above data Pt (II) and Au (III) complex show square planar structure whereas Rh (III) complex show octahedral structure.

The synthesized Rh (III) and Pt (II) metal complexes shows monoclinic crystal system by calculating cell lattice parameters whereas $\mathrm{Au}$ (III) complexes show cubic crystal system.

It was also found that Antimicrobial activities of metal complexes showed better potency against the said bacteria as compared to the Schiff base ligand.

\section{REFERENCES:}

1. J. Singh and et al Indian chem. Society 52, 656 (1975).

2. Thanh, N.D., Duc, H.T., Duyen, V.T., Tuong, P.M., Quoc, N.V., Chemistry Central Journal,60-66 ( 2015)

3. U. K. Jetley and et al chem. era 15, 23 (1979).

4. K. Lal and et al J.Inorg. Nucl. Chem., 40, 356 (1978).

5. S. K. Singh and S. B. Singh, Indian J. of Chem, 40, 1070 (2001).

6. R.K. Agarwal, L. Singh and D. K. Sharma, Bioinorganic Chemistry and Application, Article ID 59509 (2006).
7. V. K. Sharma, Shrivastava and A. Shrivastava, Bioinorganic Chemistry and Application, Article ID 68374 (2007).

8. D. Kovala-Demertzi, J. R. Miller, N. Kourkoumelis, S. K. Hadjikakou and M. A. Demertzis, Polyhedron, 18,1005 (1999).

9. E. Labisbal, K. D. Haslow, A. Sousa-Pedrares, J. ValdesMartinez, L. Hernandez-Ortega and D. X. West, Polyhedron, 22,2831 (2003).

10. M. K. Biyla, N. Fahmi and R.V. Singh, Indian J. Chem., sect $A, 43,2536$ (2003).

11. I. Pal, F. Basuli and S. Bhattacharya, Proc. Indain Acad. Sci. (Chemical Sci). 114, 255 (2002).

12. L. N. Sharda and M. C. Ganorkar, Indian J. Chem., sect A, 27,617(1988).

13. V. Chinnusamy and K. Natarajan, Synthesis and Reactivity in Inorganic, Metal-Organic and Nanometal Chemistry, 23,889 (1993).

14. A. Cukurovali, Yilmaz, H.Ozmen and M.Ahmedzada, Transition Met Chem, 27, 171(2002).

15. B. H. Mehta and D. S. Joishar, Asian J. Chem., 16, 910 (2004).

16. S. Chandra and R. Singh, Indian J. Chem., 27A, 417 (1988).

17. Mason, W. R., \& Gray, H. B."Electronic structures and spectra of square-planar gold (III) complexes", Inorganic Chemistry, 7(1), 55-58 (1968).

18. E. Bertelli, C. Preti and J. Tosi, J. Inorg. Nucl. Chem., 37,1421(1975).18.C.K. Jorgenson, "Absorption Spectra and Chemical Bonding in Complexes "Pergamon Press, New York, p. 183 (1964).

19. Alias, M., Kassum,, H., \& Shakir, C.,Synthesis, physical characterization and biological evaluation of Schiff base $M($ II) complexes. Journal of the Association of Arab Universities for Basic and Applied Sciences, 15(1), 28-34. (2014). 
20. Dent Glasser, L. K., Crystallography its Application, Van Nostrand Reinhold Co., London (1977).

21. Champika V. Hettiarachchi, Manal A. RawashdehOmary, Daniel Korir, Jehan Kohistani, Muhammed Yousufuddin, H. V. Rasika Dias,"Trinuclear Copper(I) and Silver(I) Adducts of 4-Chloro-3,5-bis (trifluoromethyl)pyrazolate and 4-Bromo-3,5 bis (trifluoromethyl)pyrazolate", Inorganic Chemistry 52, 13576-13583 (2013)

22. Abou MeHLa, K. S. A., Al-Hazmi, G. A. A., \& Refat, M. S., Russian Journal of General Chemistry,87(12), 30433051.(2017)

23. Umapathy P.,.Budhkar A. P. and Dorai C., J. of Ind. Chem. Soc., 63, 714 (1986).
24. Costa G., Tavagnacco C. and Mahajan R., Bull. Electro. Chem., 14(2), 78 (1998).

25. Kawamoto T. and Konno T., Bull. Chem. Soc. Jpn., 76, 127 (2003)

26. .Fulop F., Mattinen J. and Pihlaja K., Tetrahedron, 46, 6545 (1990)

27. Shimakoshi H., Kaieda T., Matsuo T., Sato H. and HisaedaY., Tetrahedron Letters., 44, 5197 (2003).

28. Leovac V. M., Divakovic V., Petrovic D., Argay G. and Kalman A., Polyhedron., 2, 1307 (1983).

29. Padhye S. and Kauffman G. B., Coord. Chem. rev., 63, 127 (1985) 